\title{
UPAYA MENGEMBANGKAN KEMAMPUAN BERPIKIR KRITIS MELALUI PEMBELAJARAN MENGGUNAKAN BAHAN AJAR GEOMETRI ANALITIK BERBASIS GUIDED DISCOVERY
}

\author{
Sintha Sih Dewanti \\ Program Studi Pendidikan Matematika UIN Sunan Kalijaga Yogyakarta \\ Jl. Marsda Adisucipto No 1 Yogyakarta, sintha_pmat@yahoo.com
}

\begin{abstract}
ABSTRAK
Penelitian ini bertujuan untuk mengembangkan kemampuan berpikir kritis mahasiswa melalui pembelajaran menggunakan bahan ajar geometri analitik berbasis guided discovery. Jenis penelitian ini adalah penelitian tindakan kelas dengan tahapan setiap siklusnya adalah: 1) planning; 2) acting and observing; dan 3) reflecting. Subyek dari penelitian ini adalah mahasiswa Program Studi pendidikan matematika yang menempuh mata kuliah geometri analitik pada semester genap tahun akademik 2014/2015 sebanyak 46 mahasiswa. Teknik pengumpulan data menggunakan teknik tes, wawancara, observasi, dan dokumentasi. Analisis data secara kualitatif yang didukung oleh analisis data secara kuantitatif. Keabsahan data menggunakan teknik triangulasi. Hasil penelitian menunjukkan adanya perkembangan kemampuan berpikir kritis mahasiswa melalui pembelajaran menggunakan bahan ajar geometri analitik berbasis guided discovery. Hal ini dilihat dari peningkatan kemampuan berpikir kritis pada setiap indikator dari sebelum tindakan dan ketiga siklusnya berturut-turut sebagai berikut: 1) Merumuskan masalah 42,935, 60,870, 78,261, 88,587; 2) Berpikir dengan sistematis 28,804, 38,587, 51,630, 59,783 ; 3) Menggunakan pembuktian-pembuktian dalam pemecahan masalah 22,826, 27,717, 34,783, 38,043; 4) Tidak mudah menyerah menghadapi kesulitan 41,304, 53,804, 67,935, 80,978; dan 5) Mengambil kesimpulan 35,326, 42,391, 68,478, 85,870.
\end{abstract}

Kata Kunci : kemampuan berpikir kritis, bahan ajar geometri analitik, guided discovery.

\begin{abstract}
This research aims to develop students critical thinking skills through analytic geometry guided discovery basedteaching materials. This classroom action research involves three cycle stages: 1) planning; 2) acting and observing; 3) reflecting. The subjects of this study are 46 students of Mathematics Education, who takes courses analytic geometry in the second semester of academic year 2014/2015. The data are collected by test, interviews, observation, and documentation. Qualitative data analysis is supported by quantitative data analysis. The validity of the data using triangulation techniques. The results show that the student critical thinking skills increase through this teaching materials. It is seen from the increasing in critical thinking skills on each indicator that consider to: 1) Formulating the problem 42.935, 60.870, 78.261, 88.587; 2) Systematically thinking $28.804,38.587,51.630,59.783 ; 3)$ Using the proofs in problem solving $22.826,27.717,34.783,38.043$; 4) It is not easy to give up the face of adversity 41.304, 53.804, 67.935, 80.978; and 5) Taking conclusions 35.326, 42.391, 68.478, 85.870.
\end{abstract}

Key words: critical thinking skills, analytic geometry teaching materials, guided discovery 


\section{Pendahuluan}

Berpikir merupakan suatu
aktivitas mental untuk membantu
memecahkan masalah, membuat
keputusan, atau memenuhi rasa
keingintahuan. Kemampuan berpikir
terdiri dari dua yaitu kemampuan berpikir
dasar dan kemampuan berpikir tingkat
tinggi. Kemampuan berpikir dasar (lower
order thinking) hanya menggunakan
kemampuan terbatas pada hal-hal rutin dan bersifat mekanis, misalnya menghafal dan mengulang-ulang informasi yang diberikan sebelumnya. Sementara, kemampuan berpikir tingkat tinggi (higher order thinking) membuat mahasiswa untuk mengintrepretasikan, menganalisa atau bahkan mampu memanipulasi informasi sebelumnya sehingga tidak monoton. Kemampuan berpikir tingkat tinggi (higher order thinking) digunakan apabila seseorang menerima informasi baru dan menyimpannya untuk kemudian digunakan atau disusun kembali untuk keperluan pemecahan masalah berdasarkan situasi.

Permen 22 Tahun 2006 tentang standar isi menyatakan mata pelajaran matematika diberikan kepada semua peserta didik untuk membekali mereka dengan kemampuan berpikir logis, analitis, sistematis, kritis, dan kreatif, serta kemampuan bekerjasama. Oleh karena itu, sangat diperlukan peningkatan keterampilan berpikir tingkat tinggi yang

merupakan salah satu prioritas dalam pembelajaran matematika sekolah. Sebagai calon pendidik bidang studi matematika, mahasiswa program studi pendidikan matematika juga dituntut untuk mempunyai kemampuan seperti yang menjadi tuntutan peserta didik.

Secara umum, keterampilan berpikir terdiri atas empat tingkat, yaitu: menghafal (recall thinking), dasar (basic thinking), kritis (critical thinking) dan kreatif (creative thinking) (Krulik \& Rudnick, 1999). Berpikir kritis adalah berpikir yang memeriksa, menghubungkan, dan mengevaluasi semua aspek dari situasi atau masalah. Termasuk didalamnya mengumpulkan, mengorganisir, mengingat, dan menganalisa informasi. Berpikir kritis termasuk kemampuan membaca dengan pemahaman dan mengidentifikasi materi yang dibutuhkan dan tidak dibutuhkan. Ini juga berarti mampu menarik kesimpulan dari data yang diberikan dan mampu menentukan ketidakkonsistenan dan pertentangan dalam sekelompok data.

Geometri merupakan bagian
matematika yang membahas tentang
bentuk dan ukuran dari suatu obyek yang
memiliki keteraturan tertentu (Clemens,
1985). Geometri sudah dikenalkan sejak
siswa kelas I sekolah dasar sebatas
mengenal bola dan bukan bola, tabung
dan bukan tabung, balok dan bukan
balok, lingkaran dan bukan lingkaran,

Geometri merupakan bagian

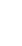


segitiga dan bukan segitiga, serta segiempat dan bukan segiempat. Di kelas-kelas berikutnya dilanjutkan dengan menggambar bangun datar dan ruang, menghitung panjang, luas, dan volume.

Di tingkat SMP, pelajaran mengenai geometri (datar dan ruang) diulang lagi dengan pendalaman dimulai dari melukis bangun datar, sudut, dua garis sejajar, dua garis tegak lurus, membagi ruas garis atas beberapa bagian yang sama panjang, membagi sudut atas 2 bagian yang sama besar, pengenalan berpikir deduktif, dalil Pythagoras hingga terapannya dalam kehidupan sehari-hari. Untuk geometri ruang meliputi mengidentifikasi bangun-bangun ruang sisi lengkung, mengidentifikasi bangun ruang sisi datar hingga menentukan besaran-basaran yang ada didalamnya.

Geometri pada tingkat SMA lebih ditekankan pada geometri ruang yaitu menentukan kedudukan, jarak, dan besar sudut yang melibatkan titik, garis, dan bidang dalam ruang dimensi tiga. Mulai tingkat SMP, penurunan rumusrumus dilakukan secara induktif agar siswa tertarik dan merasa mudah menerimanya. Namun bukti secara induktif itu sebenarnya belum sah secara matematika. Bukti dinyatakan sah jika sudah terbukti secara deduktif. Menurut psikologi perkembangan kognitif anak oleh Piaget (1896 - 1980), bukti secara deduktif semacam itu secara psikologis sudah dapat diterima oleh siswa di atas usia 11 tahun. Karena siswa SMP pada umumnya sudah berumur 11 tahun jadi tentunya mereka dapat menerima bukti secara deduktif.

Berdasarkan paparan tersebut, tampak bahwa geometri merupakan materi matematika yang menjadi perhatian utama. Sebagai calon guru bidang studi matematika, mahasiswa program studi pendidikan matematika tidak hanya dituntut untuk dapat memahami konsep geometri, akan tetapi dapat membuktikan secara sah teorema dalam geometri. Pada kurikulum 2013 program studi pendidikan matematika, geometri mulai dipelajari di semester 2 pada mata kuliah geometri analitik dengan beban 4 sks.

Ada dua pokok bahasan besar pada mata kuliah geometri analitik yaitu geometri analitik bidang dan geometri analitik ruang. Mata kuliah ini bertujuan untuk memberikan pemahaman kepada mahasiswa tentang konsep-konsep dasar di dalam geometri analitik sehingga mahasiswa dapat menyelesaikan persoalan-persoalan yang terkait dengan konsep-konsep yang ada di geometri analitik. Di samping itu, mata kuliah ini juga bertujuan untuk memberikan alat dan landasan yang kuat bagi mahasiswa untuk mempelajari mata kuliah lebih lanjut dan yang membutuhkan materi di geometri analitik, seperti mata kuliah 
kalkulus II, kalkulus multivariabel dan geometri transformasi.

$$
\text { Berdasarkan pengalaman }
$$

peneliti dalam mengampu mata kuliah geometri analitik sejak tahun 2010 terdapat beberapa kendala. Mahasiswa sering kesulitan dalam memahami konsep dan akhirnya mahasiswa hanya menghafal saja. Apabila mahasiswa hanya menghafal rumus-rumus dan teorema maka mereka tidak akan paham konsep, sehingga mereka akan kesulitan ketika dihadapkan dengan masalah geometri yang lebih kompleks dan akan berdampak pada hasil belajar yang kurang optimal. Padahal mahasiswa sebagai calon guru matematika tingkat SMP maupun SMA nantinya harus menyajikan materi geometri berangkat dari sesuatu yang konkrit kemudian ditindaklanjuti dengan gambar-gambar (semi konkrit), dan barulah diakhiri dengan lambang yang sifatnya abstrak. Selain itu, rumus-rumus geometri juga harus disertai pembuktian yang sah secara matematika.

Pada tahun 2014 peneliti telah mengembangkan bahan ajar geometri analitik berbasis guided discovery. Bahan ajar ini memuat materi untuk dipelajari mahasiswa agar mahasiswa memiliki kemampuan memahami konsep-konsep dan teorema dalam geometri melalui pendekatan geometrik-deduktif. Untuk membantu mahasiswa dalam membuktikan teorema, maka bahan ajar juga dilengkapi dengan petunjuk penemuan. Melalui penemuan terbimbing (guided discovery) diharapkan kemampuan berpikir kritis pada mahasiswa dapat berkembang. Oleh karena itu melalui penelitian ini, peneliti berupaya untuk mengembangkan kemampuan berpikir kritis melalui pembelajaran menggunakan bahan ajar geometri analitik berbasis guided discovery.

\section{Metode Penelitian}

Penelitian ini menggunakan jenis penelitian tindakan kelas (classroom action research). Penelitian tindakan kelas ini mengambil desain yang dikembangkan oleh Kemmis dan Mc Taggart yang merupakan pengembangan dari konsep Kurt Lewin. Setiap siklus terdiri dari tiga tahap, yaitu: planning berupa penyusunan rencana tindakan (skenario pembelajaran), materi perkuliahan, bahan ajar, dan instrumen penelitian; 2) acting and observing berupa mengadakan persiapan dan motivasi, pembelajaran menggunakan bahan ajar geometri analitik berbasis guided discovery (pemberian masalah, aktivitas penemuan, diskusi, mengerjakan tugas mandiri, melakukan refleksi, melakukan uji kompetensi), evaluasi proses pembelajaran, dan observasi; dan 3) reflecting.

Siklus berikutnya muncul jika indikator pada siklus sebelumnya belum 
tercapai. Siklus berikutnya dilakukan berdasarkan perencanaan dan perbaikan dari hasil refleksi siklus sebelumnya, kemudian dilakukan refleksi untuk melihat sejauh mana perubahan yang terjadi melalui tindakan yang baru. Siklus berhenti ketika indikator keberhasilan telah tercapai.

Indikator keberhasilan penelitian merupakan sesuatu yang digunakan sebagai ukuran berhasil tidaknya suatu penelitian. Indikator kemampuan berpikir kritis dikatakan berkembang jika kemampuan berpikir kritis mahasiswa mengalami peningkatan dari satu siklus ke siklus berikutnya.

Subyek dari penelitian ini adalah mahasiswa program studi pendidikan matematika yang menempuh mata kuliah geometri analitik pada semester genap tahun akademik 2014/2015 sebanyak 46 mahasiswa. Obyek dari penelitian ini adalah pembelajaran menggunakan bahan ajar geometri analitik berbasis guided discovery.

Teknik pengumpulan data pada penelitian ini menggunakan teknik tes, wawancara, observasi, dan dokumentasi. Instrumen pada penelitian ini, peneliti selaku instrumen utama dibantu dengan instrumen bantu berupa tes kemampuan berpikir kritis. Peneliti sebagai alat, peka dan dapat bereaksi terhadap segala stimulus dari lingkungan yang harus diperkirakannya bermakna atau tidak bagi penelitiannya.
Analisis data yang digunakan merupakan analisis data secara kualitatif yang didukung oleh analisis data secara kuantitatif. Peneliti menggunakan analisis data model Miles dan Huberman. Aktivitas dalam analisis data dilakukan setelah proses pengumpulan data, yaitu 1) data reduction merupakan tahap merangkum dan memfokuskan data hasil analisis penelitian serta menghilangkan data yang tidak terpola, kemudian datadata dikumpulkan dan dipilih sesuai dengan tujuan penelitian; 2) data display, data yang telah direduksi disajikan dalam bentuk uraian singkat sehingga mudah untuk dibaca dan dipahami baik secara keseluruhan maupun bagian-bagiannya; dan 3) conclusion drawing/ verivication, kesimpulan diambil berdasarkan hasil analisis dari semua data yang telah diperoleh.

Analisis data kuantitatif berupa analisis data angket pelaksanaan pembelajaran dan data tes kemampuan berpikir kritis. Data angket pelaksanaan pembelajaran digunakan untuk mendapatkan kesimpulan mengenai implementasi pembelajaran menggunakan bahan ajar geometri analitik berbasis guided discovery dalam mengembangkan kemampuan berpikir kritis.

Analisis data kuantitatif yang berupa hasil tes, dilakukan dengan analisis dengan metode perbandingan tetap (the constant comparative method) 
untuk mengetahui reliabilitas penjenjangan kemampuan berpikir kritis yang dirumuskan. Pada penelitian ini, reliabilitas dipenuhi jika temuan teori yang didasarkan pada suatu saat pengumpulan data memberikan hasil yang identik atau "sama" (konsisten) dengan hasil teori yang telah dirumuskan sebelumnya. Untuk mengetahui reliabilitas temuan teori dilakukan analisis perbandingan tetap. yaitu membandingkan suatu kategori data tertentu dengan suatu kategori data tertentu lain sehingga didapat suatu kategori yang memiliki ciri-ciri sama dan tetap. Suatu kategori yang bersifat tetap ini merupakan teori yang dihasilkan.

Analisis tugas tertulis penyelesaian masalah dilakukan dengan memeriksa kebenaran jawaban soal pada Uji Kompetensi pada tiap akhir bab pada bahan ajar, kemudian melihat aspekaspek kejelasan, ketepatan, ketelitian, relevansi, kelogisan, kedalaman, dan keluasan dalam aktivitas berpikir kritis menyelesaikan masalah matematika. Setelah itu, ditentukan dugaan tingkat berpikir kritis subjek tersebut. Bila masih terdapat aspek-aspek yang belum jelas ditriangulasi dengan wawancara. Analisis data hasil wawancara dilakukan dengan langkah reduksi, pemaparan data, menarik kesimpulan dari data yang telah dikumpulkan dan diverifikasi kesimpulan dari data yang telah dikumpulkan dan memverifikasi kesimpulan tersebut. Hasil analisis wawancara akan digunakan sebagai triangulasi terhadap hasil analisis tes tulis.

\section{Hasil dan Pembahasan}

Penelitian ini terdiri dari tiga siklus dengan indikator perkuliahan sebagai berikut: 1) Menjelaskan persamaan lingkaran dan garis singgung pada lingkaran; 2) Menjelaskan persamaan ellips dan garis singgung pada ellips; dan 3) Menjelaskan persamaan hiperbola dan garis singgung pada hiperbola.

Prosedur pelaksanaan perkuliahan adalah: 1) dosen memberikan pengarahan; 2) mahasiswa dibentuk ke dalam kelompok beranggotakan 4 atau 5 orang; 3) pembelajaran menggunakan bahan ajar geometri analitik berbasis guided discovery yaitu pemberian masalah; 4) aktivitas penemuan (mahasiswa berdiskusi untuk memecahkan masalah); 5) perwakilan kelompok mempresentasikan hasil diskusi (beberapa hal yang perlu diklarifikasi); 6) kelompok lain memberikan tanggapan dan klarifikasi dari dosen; 7) mahasiswa mengerjakan tugas mandiri; 8) mahasiswa melakukan refleksi; dan 9) mahasiswa melakukan uji kompetensi.

Berdasarkan analisis awal karakteristik mahasiswa, diketahui bahwa mahasiswa masih belum bisa memahami materi geometri analitik dengan baik. 
Pengetahuan mahasiswa masih sebatas pada hafalan rumus-rumus, mahasiswa belum bisa mengkonstruksi pengetahuannya sendiri dengan baik. Hal ini berakibat pada hasil belajar yang dicapai sebagian besar mahasiswa masih rendah. Selain itu, kemampuan mahasiswa untuk berpikir terbuka, membuktikan teorema, dan mengevaluasi juga masih kurang.

Berdasarkan analisis tersebut, mahasiswa membutuhkan bahan ajar yang dapat mengkonstruksi pengetahuannya sehingga dapat memfasilitasi kemampuan berpikir kritis. Dengan diberikan masalah pada bahan ajar diharapkan mahasiswa dapat mengkostruksi pengetahuannya, selain itu dengan menyelesaikan masalah, mahasiswa dapat mengembangkan kemampuan berpikir kritis. Hal tersebut sesuai dengan pendapat Hamruni (2012) bahwa belajar bukan menghafal, akan tetapi proses mengkonstruksi pengetahuan sesuai dengan pengalaman yang mereka miliki. Proses mengkonstruksi pengetahuan tersebut melalui masalah-masalah yang diselesaikan melalui kegiatan penemuan (metode penemuan). Melalui pemberian masalah, mereka dihadapkan pada aktivitas untuk menemukan konsep. Menurut Borthick dan Jones (2000) bahwa metode penemuan menjelaskan tentang peserta didik belajar untuk mengenal suatu masalah, karakteristik dari solusi, mencari informasi yang relevan, membangun strategi untuk mencari solusi, dan melaksanakan strategi yang dipilih. Dengan kata lain metode penemuan itu membiasakan mahasiswa dalam memecahkan masalah dan berpikir kritis.

Berdasarkan hasil analisis data, terdapat peningkatan kemampuan berpikir kritis. Ada 5 indikator kemampuan berpikir kritis yaitu: 1) merumuskan masalah, 2) berpikir dengan sistematis, 3) menggunakan pembuktianpembuktian dalam pemecahan masalah, 4) tidak mudah menyerah menghadapi kesulitan, dan 5) mengambil kesimpulan. Berikut ini adalah rata-rata skor tes kemampuan berpikir kritis dengan skor maksimal 100.

Tabel 1. Rata-rata Skor Tes Kemampuan Berpikir Kritis

\begin{tabular}{|c|c|c|c|c|c|}
\hline \multirow{2}{*}{$\begin{array}{c}\text { No } \\
\text {. }\end{array}$} & \multirow{2}{*}{$\begin{array}{l}\text { Indikator Kemampuan } \\
\text { Berpikir Kritis }\end{array}$} & \multirow{2}{*}{$\begin{array}{l}\text { Sebelum } \\
\text { Tindakan }\end{array}$} & \multicolumn{3}{|c|}{ Sesudah Tindakan } \\
\hline & & & Siklus I & Siklus II & Siklus III \\
\hline 1 & Merumuskan masalah & 42,935 & 60,870 & 78,261 & 88,587 \\
\hline 2 & Berpikir dengan sistematis & 28,804 & 38,587 & 51,630 & 59,783 \\
\hline 3 & $\begin{array}{l}\text { Menggunakan pembuktian-pembuktian } \\
\text { dalam pemecahan masalah }\end{array}$ & 22,826 & 27,717 & 34,783 & 38,043 \\
\hline 4 & $\begin{array}{l}\text { Tidak mudah menyerah menghadapi } \\
\text { kesulitan }\end{array}$ & 41,304 & 53,804 & 67,935 & 80,978 \\
\hline 5 & Mengambil kesimpulan & 35,326 & 42,391 & 68,478 & 85,870 \\
\hline & Rata-rata Kemampuan Berpikir Kritis & 34,239 & 44,674 & 60,217 & 70,652 \\
\hline
\end{tabular}




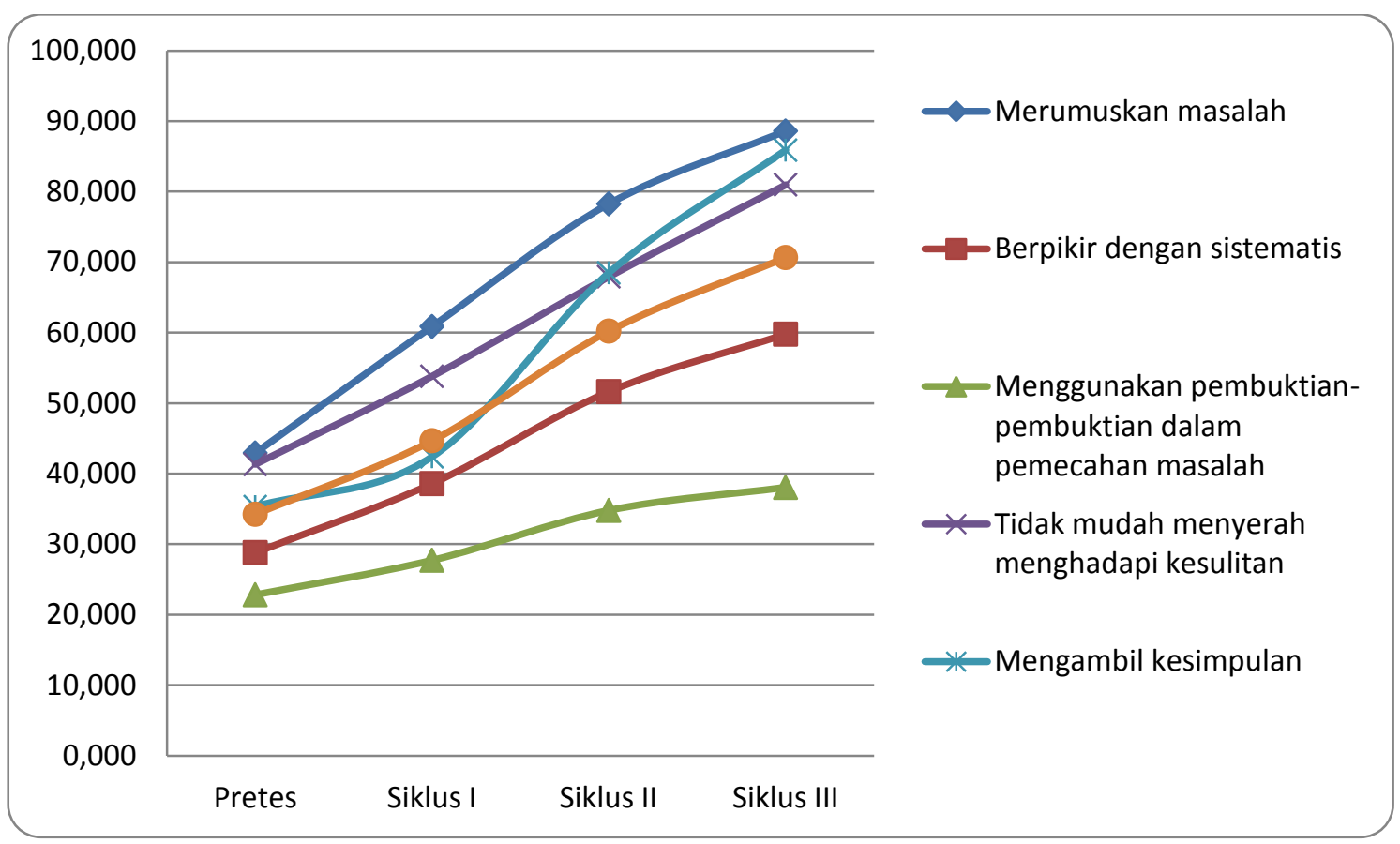

Gambar 1. Grafik Peningkatan Kemampuan Berpikir Kritis

Berdasarkan tabel dan grafik di atas menunjukkan bahwa ada peningkatan kemampuan berpikir kritis mahasiswa pada setiap indikator. Kemampuan berpikir kritis paling tinggi pada indikator merumuskan masalah, sedangkan kemampuan berpikir kritis paling rendah pada indikator menggunakan pembuktian-pembuktian dalam pemecahan masalah. Akan tetapi selalu ada peningkatan kemampuan berpikir kritis mahasiswa pada setiap siklusnya.

Siklus berikutnya dilakukan berdasarkan perencanaan dan perbaikan dari hasil refleksi siklus sebelumnya adalah dosen membantu mahasiswa mengembangkan keterampilan berpikir kritis dengan beberapa cara yaitu:
1. Dosen mengajak mahasiswa menghindari pemikiran sempit dan mendorong mereka untuk mengeksplorasi opsi-opsi.

2. Dosen mendorong mahasiswa untuk bertanya, merenungkan, menyelidiki dan meneliti. Aspek lain dari keingintahuan intelektual adalah mengenali problem dan inkosistensi,

3. Dosen bekerjasama dengan mahasiswa dalam menyusun rencana, menentukan tujuan, mencari arah dan menciptakan hasil,

4. Dosen mendorong mahasiswa untuk mengecek ketidakakuratan dan kesalahan, bersikap cermat dan teratur.

Hal tersebut sesuai dengan pendapat John W. Santrok (2007), ada beberapa yang dapat digunakan dosen 
untuk membantu perkembangan mahasiswa adalah: 1) berpikiran terbuka; 2) rasa ingin tahu intelektual; 3) perencanaan dan strategi; dan 4) kehatihatian intelektual.

Dalam perkuliahan geometri analitik, dosen dapat memasukkan pemikiran kritis dalam pengajaran dengan cara sebagai berikut:

1. Seorang dosen jangan hanya menanyakan apa yang terjadi, tetapi juga menanyakan bagaimana dan mengapa dapat terjadi.

2. Mengkaji dugaan fakta untuk mengetahui apakah ada bukti yang mendukungnya.

3. Berdebat secara rasional bukan emosional.

4. Mengakui bahwa terkadang ada lebih dari satu jawaban atau penjelasan yang baik.

5. Membandingkan berbagai jawaban untuk suatu pertanyaan dan dinilai mana yang benar-benar jawaban terbaik.

6. Mengevaluasi dan kalau mungkin menanyakan apa yang dikatakan seseorang, bukan sekedar menerima begitu saja jawaban sebagai kebenaran.

7. Mengajukan pertanyaan dan pikiran di luar apa yang sudah diketahui untuk menciptakan ide baru atau informasi baru.

Kemampuan berpikir memerlukan kemampuan mengingat dan memahami, oleh sebab itu kemampuan mengingat adalah bagian terpenting dalam mengembangkan kemampuan berpikir. Kemampuan berpikir seseorang akan diikuti oleh kemampuan mengingat dan memahami. Seseorang yang mempunyai daya ingat yang baik, dapat menyimpan berbagai informasi dalam waktu yang lama sehingga dapat digunakan untuk menyelesaikan berbagai masalah yang dihadapi di masa mendatang.

Dalam melaksanakan berpikir kritis, terlibat disposisi berpikir yang dicirikan dengan: bertanya secara jelas dan beralasan, berusaha memahami dengan baik, menggunakan sumber yang terpercaya, mempertimbangkan situasi secara keseluruhan, berusaha tetap mengacu dan relevan ke masalah pokok, mencari berbagai alternatif, bersikap terbuka, berani mengambil posisi, bertindak cepat, bersikap atau berpandangan bahwa sesuatu adalah bagian dari keseluruhan yang kompleks, memanfaatkan cara berpikir orang lain yang kritis, dan bersikap sensitif terhadap perasaan orang lain.

Hasil tes kemampuan berpikir kritis tersebut didukung oleh proses perkuliahan di kelas yang sudah berjalan dengan baik, hal ini terlihat dari mahasiswa lebih antusias dan aktif dalam mengikuti perkuliahan, mahasiswa juga mempunyai motivasi untuk mempelajari geometri analitik. Hal ini sesuai dengan pernyataan Eggen (2012) yang 
menyatakan bahwa guided discovery (penemuan terbimbing) dapat efektif meningkatkan motivasi siswa karena keterlibatan siswa yang tinggi yang berkontribusi pada motivasi belajar.

Terkait dengan perkuliahan menggunakan bahan ajar geometri analitik berbasis guided discovery, manfaat yang didapatkan adalah mahasiswa memiliki kesempatan untuk mengemukakan ide atau gagasan yang dimilikinya, sehingga hal itu akan dapat meningkatkan kemampuan mahasiswa. Di samping itu, bahan ajar geometri analitik berbasis guided discovery mengajak mahasiswa untuk menganalisa dan mencari kebenaran dari suatu masalah yang sedang dibahas, mampu berpikir sistematis, terarah dan mempunyai tujuan yang jelas. Selain itu peran dosen dalam kegiatan perkuliahan dengan menggunakan bahan ajar geometri analitik berbasis guided discovery adalah sebagai pemimpin, pembimbing, dan fasilitator. Dalam pembelajaran dengan menggunakan bahan ajar geometri analitik berbasis guided discovery yang paling utama adalah memberikan kondisi yang seluasluasnya kepada mahasiswa untuk memperoleh pengalaman bagaimana mengkonstruksi pengetahuan itu sendiri. Oleh karena itu, mahasiswa ditempatkan sebagai pusat dalam proses kegiatan perkuliahan, baik yang dilakukan secara individu maupun secara kelompok.

\section{Kesimpulan}

Berdasarkan hasil penelitian dapat disimpulkan bahwa adanya perkembangan kemampuan berpikir kritis mahasiswa melalui pembelajaran menggunakan bahan ajar geometri analitik berbasis guided discovery. Hal ini dilihat dari peningkatan kemampuan berpikir kritis pada setiap indikator dari sebelum tindakan dan ketiga siklusnya berturut-turut sebagai berikut:

1. Merumuskan masalah $42,935,60,870$, 78,261, 88,587;

2. Berpikir dengan sistematis 28,804 , 38,587, 51,630, 59,783;

3. Menggunakan pembuktianpembuktian dalam pemecahan masalah 22,826, 27,717, 34,783, 38,043 ;

4. Tidak mudah menyerah menghadapi kesulitan 41,304, 53,804, 67,935, 80,978; dan

5. Mengambil kesimpulan 35,326, $42,391,68,478,85,870$.

\section{Ucapan Terimakasih}

Pada kesempatan ini, tidak lupa saya ucapkan terimakasih kepada:

1. Lembaga Penelitian dan Pengabdian kepada Masyarakat (LPPM) UIN Sunan Kalijaga Yogyakarta yang telah memberikan bantuan dana penelitian.

2. Dosen program studi pendidikan matematika yang telah berkontribusi 
dalam diskusi terkait dengan penelitian.

3. Semua pihak yang tidak dapat peneliti sebutkan satu per satu yang telah membantu dalam penelitian ini.

\section{Pustaka}

Borthick, A.F. dan Jones, D.R. 2000. The motivation for collaborative discovery learning online and its application in an information systems assurance course. Issues in Accounting Education.

Bruce Joyce dan Marsha Weil. 1992. Models of teaching. Massachussetts: Allyn and Bacon.

Clemens, Stanley R. Cs. 1985. Geometry. USA: Addison-Westley

Publishing Company, inc.

Cooney, Darvis. 1975. Dynamics of teaching secondary school mathematics. USA: Houghton Mifflin Company.

Depdiknas. 2006. Permendiknas No.22 tentang: Standar isi. Jakarta: Depdiknas.

Depdiknas. 2008. Panduan pengembangan bahan ajar. Jakarta: Depdiknas.

Eggen, Paul \& Don Kauchak. 2012. Strategi dan Model Pembelajaran Mengajarkan Konten dan Keterampilan Berpikir (Edisi Keenam). Jakarta: PT Indeks.
Hamruni. 2012. Strategi dan modelmodel pembelajaran aktif dan menyenangkan. Yogyakarta: Investidaya.

John W. Santrok. 2007. Psikologi pendidikan (edisi ke 2). Jakarta: Kencana Prenada Media Grup.

Jozua Subandar. 2010. Thinking classroom dalam pembelajaran matematika di sekolah. http: learnweb.harvard.edu/ALPS/think ing/intro.cfm.

Kindle, Yoseph,.H. Theory and problems in plane and solid analytic geometry. New York: Schaums Publishing Co.

Kletenick D. 1982. Problems in analytic geometry. Moscow: Peace Publishers.

Soedjadi. 1999. Kiat pendidikan matematika di Indonesia konstatasi keadaan masa kini menuju harapan masa depan. Jakarta: Depdikbud.

Sugiyono. 2010. Metode Penelitian Pendidikan Pendekatan Kuantitatif, Kualitatif, dan $R \& D$. Bandung: Alfabeta.

Voigt, Jorg. 1996. Theories of mathematical learning. New Jersey. Lawrence Erlbaum Associates Publishers. 
